\title{
Hemodynamic Dysfunctions in COVID-19 Patients
}

\author{
Disfunções Hemodinâmicas nos Pacientes com COVID-19 \\ Disfunciones hemodinámicas en pacientes con COVID-19
}

Received: 09/07/2021 | Reviewed: 09/12/2021 | Accept: 09/13/2021 | Published: 09/14/2021

\author{
Rubens Barbosa Rezende \\ ORCID: https://orcid.org/0000-0002-5421-0519 \\ Santa Rita College, Brazil \\ E-mail: rubensrezende420@gmail.com
}

\begin{abstract}
Coronavirus disease 2019 (COVID-19) is a respiratory viral infection caused by the novel coronavirus (SARS-CoV2). Thus, it objected to comprehend the pathophysiology of COVID-19, as well as its clinical repercussions on hemodynamic alterations. This is an integrative literature review, such a method is able to select and include experimental and non-experimental studies, qualitative in nature, descriptive and exploratory in character. Initially, it started from the guiding question: "What hemodynamic dysfunctions can the positive COVID-19 patient develop?" The study was conducted by searching the database: PUBMED, using the descriptors: "coagulopathy" and "COVID19", combined by the Boolean operator AND. As inclusion criteria, the filters of one-year version, full text, clinical trial, meta-analysis, and randomized controlled trial were chosen. Coagulopathy and thromboembolic events are manifestations of COVID-19 and are designated as poor prognostic factors. The respiratory system is the main target of SARS-CoV-2, but other body systems may also be involved. Therefore, symptoms can range from respiratory distress to multiple organ failure. It is concluded that the presence of coagulopathy is a major source of mortality in COVID-19 positive patients. Also, coagulopathy is linked to the severity of the symptomatology of COVID-19, and that in more severe cases relatively increased levels of D-dimer, prothrombin time, and fibrinogen are present. In addition, no significant minimization in platelet levels was observed in severe cases of COVID-19.
\end{abstract}

Keywords: Coagulation; Coagulopathy; Coronavirus; COVID-19.

\section{Resumo}

A doença do coronavírus 2019 (COVID-19) é uma infecção respiratória viral ocasionada pelo novo coronavírus (SARS-CoV-2). Dessa forma, objetivou-se compreender a fisiopatologia da COVID-19, bem como as suas repercussões clínicas nas alterações hemodinâmicas. Trata-se de uma revisão integrativa da literatura, tal método é capaz de selecionar e incluir estudos experimentais e não-experimentais, de natureza qualitativa, caráter descritivo e exploratório. Inicialmente partiu-se da questão norteadora: "Quais disfunções hemodinâmicas o paciente COVID-19 positivo pode desenvolver?" O estudo foi realizado através da busca na base de dados: PUBMED, utilizando-se os descritores: "coagulopathy" e "COVID-19", combinados pelo operador booleano AND. Como critério de inclusão, elegeram-se os filtros de versão um ano, texto completo, ensaio clínico, meta-análise e teste controlado e aleatório. Coagulopatia e eventos tromboembólicos são manifestações da COVID-19 e são designadas como fatores de mau prognóstico. O sistema respiratório é o principal alvo do SARS-CoV-2, mas outros sistemas do corpo também podem estar envolvidos. Portanto, os sintomas podem variar de dificuldade respiratória a falência de múltiplos órgãos. Conclui-se que a presença de coagulopatia é uma das principais origens de mortalidade em pacientes com COVID-19 positivo. Bem como, a coagulopatia está ligada à gravidade da sintomatologia da COVID-19, e que em casos mais graves tem-se a presença de níveis relativamente aumentados de dímero $\mathrm{D}$, tempo de protrombina e fibrinogênio. Além disso, não foi observado minimização significativa nos níveis de plaquetas em casos graves de COVID-19.

Palavras-chave: Coagulação; Coagulopatia; Coronavírus; COVID-19.

\section{Resumen}

La enfermedad por coronavirus 2019 (COVID-19) es una infección viral respiratoria causada por el nuevo coronavirus (SARS-CoV-2). Así, nos propusimos comprender la fisiopatología de la COVID-19, así como sus repercusiones clínicas en los cambios hemodinámicos. Se trata de una revisión bibliográfica integradora, dicho método es capaz de seleccionar e incluir estudios experimentales y no experimentales, de naturaleza cualitativa, de carácter descriptivo y exploratorio. Inicialmente se partió de la pregunta guía: "¿Qué disfunciones hemodinámicas puede desarrollar el paciente COVID-19 positivo?" El estudio se realizó mediante una búsqueda en la base de datos: PUBMED, utilizando los descriptores: "coagulopathy" y "COVID-19", combinados por el operador booleano AND. Como criterios de inclusión, se eligieron los filtros de versión de un año, texto completo, ensayo clínico, meta-análisis y ensayo controlado aleatorio. La coagulopatía y los eventos tromboembólicos son manifestaciones de COVID-19 y se designan como factores de mal pronóstico. El sistema respiratorio es el principal objetivo del SARS-CoV-2, pero 
también pueden estar implicados otros sistemas corporales. Por lo tanto, los síntomas pueden ir desde la dificultad respiratoria hasta el fallo de múltiples órganos. Se concluye que la presencia de coagulopatía es una fuente importante de mortalidad en los pacientes COVID-19 positivos. Asimismo, la coagulopatía está relacionada con la gravedad de los síntomas de la COVID-19, y en los casos más graves se observa la presencia de niveles relativamente elevados de dímero D, tiempo de protrombina y fibrinógeno. Además, no se observó una minimización significativa de los niveles de plaquetas en los casos graves de COVID-19.

Palabras clave: Coagulación; Coagulopatía; Coronavirus; COVID-19.

\section{Introduction}

Coronavirus disease 2019 (COVID-19) is a respiratory viral infection caused by the novel coronavirus (SARS-CoV2), in which it is a member of the betacoronavirus family. It is composed of single-stranded RNA with typical structural protein involving envelope (E protein), membrane (M protein), nucleocapsid (N protein), and spicule/spike (S protein) proteins that are responsible for viral infection. The S protein on the surface of SARS-CoV-2 binds to the human receptor ACE2 (Angiotensin-converting enzyme 2), in which it is a transmembrane protein, which in turn transfers its genetic material to the cell, which then starts its replication process (Brandão, et al., 2020).

In March 2020, the World Health Organization (WHO) declared the disease a global pandemic. In which on May 22, 2020, a total of 5,061,476 cases registered worldwide, and of these, 331,475 died (Zhang, et al., 2020). Right after MERS and SARS, COVID-19 is the third most fatal coronavirus-caused zoonotic disease that has occurred in the past 20 years; however, it has generated more deaths than MERS or SARS. Furthermore, COVID-19 has a high mortality rate (Al-Ani, Chehade, LazoLangner, 2020; Zhang, et al., 2020).

As well as, recently it was found that in a pooled analysis a relevant elevation in D-dimer (DD) levels was pointed out as a predictor of persistent adverse outcomes in COVID-19, proposing the existence of underlying coagulopathy. The literature reports that there is growing evidence that severe COVID-19 may be linked to a pro-hemostatic state with a potential effect on the risk of thromboembolism, and the nature and extent of these abnormalities are not yet well understood (Al-Ani, Chehade, Lazo-Langner, 2020). Thus, we aimed to understand the pathophysiology of COVID-19, as well as its clinical repercussions on hemodynamic changes.

\section{Methodology}

This is an integrative literature review, such method is able to select and include experimental and non-experimental studies (Whittemore \& Knafl, 2005), of qualitative nature, in which the procedures are characterized by means of interpretation of phenomena by the author, without exposing or calculating events, and, generally, statistical instruments are not used to evaluate the information (Pereira, et al., 2018). As well, the research has a descriptive character, aiming to assimilate the studied phenomenon and its particularities, with the intention of specifying exactly the events and phenomena of an established fact (Triviños, 1987; Godoy, 1995). It is also exploratory, since it is intended to broaden the understanding of a given phenomenon (Gil, 2002). Initially we started from the guiding question: "What hemodynamic dysfunctions can the positive COVID-19 patient develop?" The study was conducted by searching the database: PUBMED, using the descriptors: "coagulopathy" and "COVID-19", combined by the Boolean operator AND.

As inclusion criteria, the filters of one-year version, full text, clinical trial, meta-analysis, and randomized controlled trial were chosen. And as exclusion criteria, we discarded articles that did not cover the scope of analysis, as well as studies that did not meet the guiding question, Figure 1. 
Figure 1 - Methodological flowchart.

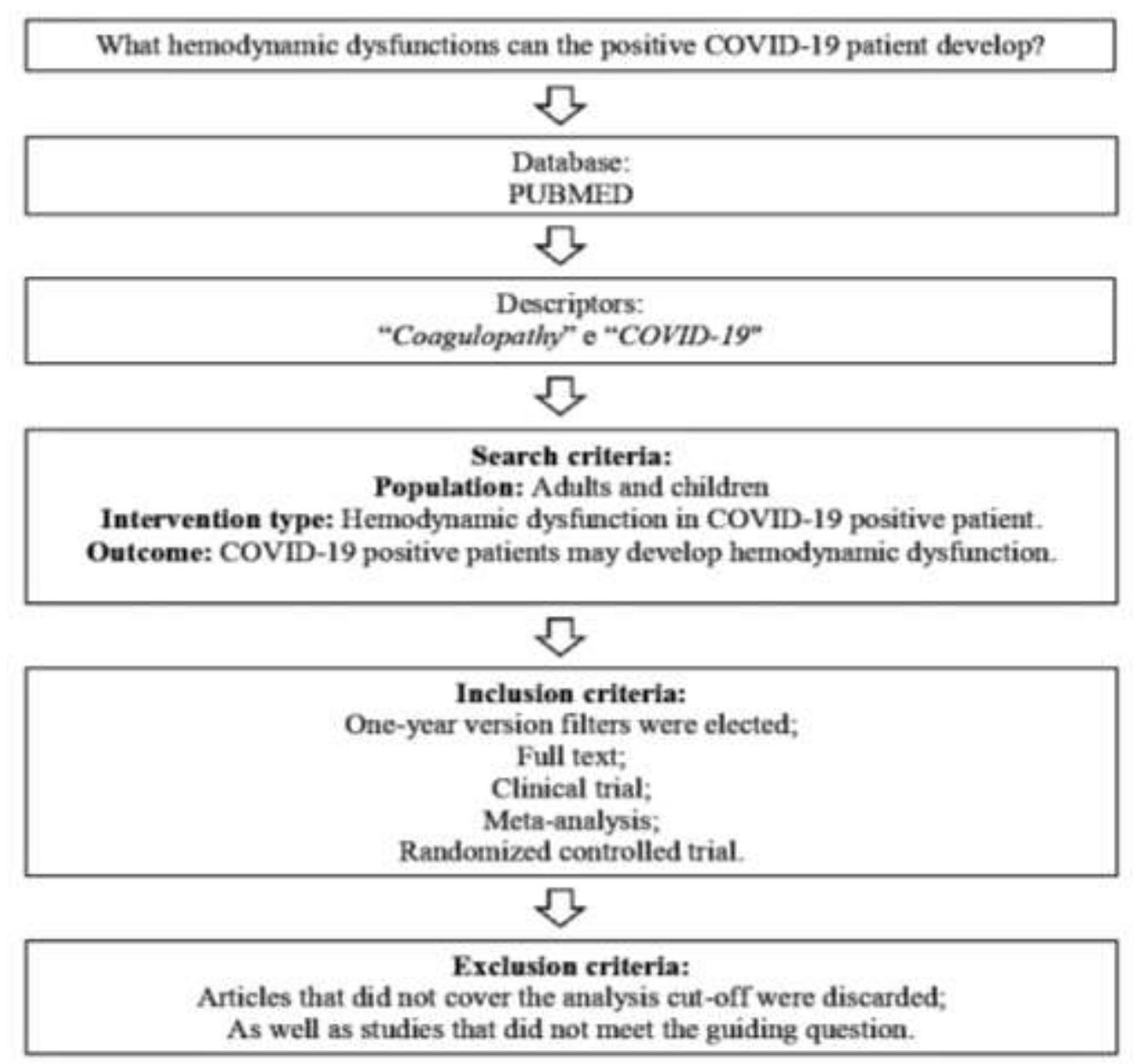

Source: Author (2021).

Based on the guiding question, the descriptors were crossed, resulting in 25 articles available in full, which were selected based on the eligibility criteria, initially by reading the titles, followed by the abstracts and full texts. Thus, 21 articles were selected to compose the study and one more for methodological support.

\section{Results and Discussion}

As a short-term result of COVID-19, the lung is still the most frequent organ of severe injury, manifested as pneumonia and respiratory failure, which are the leading causes of death in the acute phase. Surviving patients are at risk for chronic respiratory complications. Those with severe disease have a high incidence of post-viral pulmonary fibrosis, pulmonary thromboembolism, and associated dysfunction (Leung, et al., 2020).

However, a recent study showed that COVID-19-associated coagulopathy (CAC) has different characteristics than coagulopathy caused by bacterial infections and other diseases. CAC usually manifests as increased levels of DD and fibrinogen (FIB), but there are almost no abnormalities in prothrombin time (PT) and platelet count (PLT) in the early stages of the disease (Iba, et al., 2020).

Coagulopathy and thromboembolic events are manifestations of COVID-19 and are designated as poor prognostic factors. The respiratory system is the main target of SARS-CoV-2, but other body systems may also be involved. Therefore, symptoms can range from respiratory difficulty to multiple organ failure. The degree of disruption of the immune and inflammatory processes is the main determinant of the pathogenesis and severity of COVID-19. And in its severe version, the 
overproduction of pro-inflammatory cytokine storms can lead to the subsequent risk of hypercoagulability, blood vessel hyperpermeability, multiple organ failure, and even death. These findings are supported by high reporting rates of venous thromboembolism (VTE), pulmonary embolism (PE), and pulmonary thrombosis in situ (Kamel, et al., 2021).

In addition to thromboembolic events, the interaction between coagulation and inflammation has a major impact on disease progression, and may negatively affect the outcomes of COVID-19 management. Recent evidence indicates that the lung injury caused by SARS-CoV-2 represents a cytokine storm response similar to an allergic response. Based on this evidence, cytokine storms should be given the same priority as traditional cases of anaphylaxis (Kamel, et al., 2021).

SARS-CoV-2 infection is actually related to pulmonary embolism, deep vein thrombosis, and microthrombosis. The pro-inflammatory environment caused by the infection leads to endothelial dysfunction, which may be the cause of the imbalance between pro-thrombotic and antithrombotic factors. The resulting hyperthrombotic state carries a unique signature, which overlaps to some extent with disseminated intravascular coagulation (DIC) that has yet to be fully discovered (Libby \& Lüscher, 2020).

So much attention is being paid to this aspect that it is assumed that COVID-19 was previously considered a respiratory disease, but its more severe form can be defined as an endothelial disease (Libby \& Lüscher, 2020). The clinical manifestations of severe acute respiratory syndrome associated with Coronavirus Acute Respiratory Syndrome 2 (SARS-CoV2)/COVID-19 are usually related to coagulopathy. Elevated DD is associated with poor prognosis of patients with COVID-19. In a recent cohort study, $71 \%$ of patients who died met International Society of Thrombosis and Haemostasis (ISTH) criteria for CID, compared with $0.6 \%$ of surviving patients. In two recent studies, the authors described that patients affected by COVID-19 exhibit a state of hypercoagulability, but do not show the characteristic signs of CID (Chistolini, et al., 2020).

However, the nature of this coagulopathy not well clarified. The clinical evidence being that this coagulopathy associated with COVID-19 is linked to an increased risk of arterial and venous thrombotic events. The management of these thromboembolic complications is based on the use of heparin in the absence of contraindications. The risk/benefit of heparin use, as well as the initiation of anticoagulants and at what dose, is controversial (Chistolini, et al., 2020).

Goshua and colleagues (2020) found a strong link of CID and mortality in patients with COVID-19 in a single center study from China. However, other studies have proposed that the pathophysiology of COVID-19-related coagulopathy is distinct from CID. With this, the presence of viral inclusions in endothelial cells and endothelitis, consistent with reports that in small autopsy series of patients with COVID-19, along with the identification of the ACE2 receptor in vascular endothelial cells, proposed the suspicion of endothelial cell injury or activation as a central feature of the pathophysiology of COVID-19, particularly in the course of the inflammatory phase of the disease (Goshua, et al., 2020).

Zhang and colleagues (2020) reported that COVID-19-linked coagulopathy is described by elevated levels of prothrombin time (PT), activated partial thromboplastin time (APTT) and DD. As well, many studies have shown that increased DD levels are linked to nosocomial mortality. Furthermore, in the United States, recent autopsy reports have exhibited that in addition to lung lesions, critically ill patients with COVID-19 have demonstrated a hypercoagulable state evidenced by thrombotic events in the lung, kidney, and theoretically in the heart and other organs. However, whether coagulopathy is linked to the severity of COVID-19 has not yet been well clarified (Zhang, et al., 2020).

Ibañez and colleagues (2020) reported that patients with COVID-19 demonstrated a state of hypercoagulability with a thromboelastometry pattern mainly described by a minimized fibrinolytic ability in conjunction with elevated DD levels, especially seen in hyperfibrinolysis. The minimized fibrinolytic ability, was consistently described in both septic and nonseptic patients at the onset of ICD. As well, the role of the fibrinolytic system is intensely disrupted in severe sepsis and is linked to organ dysfunction (Ibañez, et al., 2020).

Elevated DD and PT levels indicate that the fibrinolytic system is activated in critically ill COVID-19 positive 
patients (Thachil, et al., 2020), but few studies have evaluated FIB levels (Ranucci, et al., 2020). Activation of the coagulation cascade in response to viral infections is a host's own defense mechanism to limit the spread of pathogens. However, the increased release of cytokines in the course of viral infections incites pro-coagulant reactions that lead to coagulation. Furthermore, endothelial cell damage and activation are capable of modifying the natural antithrombotic state due to virus tropism for ACE2 receptors (Thachil, et al., 2020).

Although coagulation dysfunction is reminiscent of CID, CAC does not cause clinical bleeding and is therefore different from CID (Connors \& Levy, 2020). Clinical observations have shown that CAC is described by high fibrinogen and nearly normal PLT counts (Connors \& Levy, 2020). This may be explained by extramedullary megakaryocytes in microvessels detected by autopsy from COVID-19 positive patients. Since, megakaryocytes are able to actively produce PLT in the peripheral circulation (Fox, et al., 2020).

Many studies have shown that fibrinogen levels elevated significantly in the early and progressive stages of viral infection, but this may reflect a hypercoagulable state rather than a perdulatory coagulopathy (Bahrami, et al., 2020). Ranucci and colleagues (2020) reported a comprehensive analysis of coagulation during intensive care unit admission. The mean fibrinogen level was $7.8 \mathrm{~g} / \mathrm{L}$ and coagulation strength was increased by thromboelasticity. SARS-CoV-2 infection usually triggers a cytokine storm dominated by interleukin-6 (IL-6) (Bahrami, et al., 2020), which stimulates fibrinogen synthesis.

Furthermore, changes in fibrinogen levels depend on the stage of infection. Tang and colleagues (2020) reported that although fibrinogen level was elevated or normal at the time of admission, its level minimized at the end stage of COVID-19, this may be occasioned by sepsis-induced coagulopathy. Since non-normal coagulation parameters, including increased DD and fibrin degradation products, are linked to higher mortality from COVID-19, and with that, monitoring of coagulation parameters is essential for the treatment of COVID-19 (Zhang, et al., 2020).

Elevated DD is nonspecific and is usually associated with many medical conditions, such as infection, trauma, or even hospitalization; however, in the context of COVID-19 infection, it has been reported as a marker of poor prognosis linked to a critical course and higher mortality. A pooled analysis showed that patients with severe COVID-19 had higher DD values than mild patients and therefore its measurement is likely to be linked to the evolution to a worse clinical picture although emerging evidence may propose conflicting results (Bemtgen, et al., 2021).

\section{Conclusion}

Thus, it is concluded that the presence of coagulopathy is one of the main origins of mortality in patients with positive COVID-19. Also, coagulopathy is linked to the severity of the symptomatology of COVID-19, and that in more severe cases there is the presence of relatively increased levels of D-dimer, PT, and FIB. Furthermore, no significant minimization in PLT levels was observed in severe cases of COVID-19. Finally, it is suggested that dynamic monitoring of coagulation parameters in hospitalized COVID-19 patients is critical to predict disease progression with unfavorable outcome and early thrombotic events.

However, more studies and experiments associating COVID-19 with hemodynamic dysfunctions are needed, as well as verification of possible changes in tests during and after the disease, since the understanding of possible sequelae associated with COVID-19 is still essential.

\section{References}

Al-Ani, F., Chehade, S., Lazo-Langner, A. (2020). Thrombosis risk associated with COVID-19 infection. A scoping review. Thromb Res. 192, 152-160. 10.1016/j.thromres.2020.05.039.

Bahrami, M., et al. (2020). Cytokine storm in COVID-19 and parthenolide: preclinical evidence. Phytother Res. 34, 2429-30. 10.1002/ptr.6776. 
Bemtgen, X., et al. (2021). Thrombotic circuit complications during venovenous extracorporeal membrane oxygenation in COVID-19. J Thromb Thrombolysis. 51(2), 301-307. 10.1007/s11239-020-02217-1.

Brandão, S. C. S. et al. (2020). COVID-19 grave: entenda o papel da imunidade, do endotélio e da coagulação na prática clínica. Jornal Vascular Brasileiro [online]. 19, e20200131. 10.1590/1677-5449.200131.

Chistolini, A., et al. (2020). Effect of low or high doses of low-molecular-weight heparin on thrombin generation and other haemostasis parameters in critically ill patients with COVID-19. Br J Haematol. 190(4), e214-e218. 10.1111/bjh.17003.

Connors, J. M. \& Levy, J. H. (2020). COVID-19 and its implications for thrombosis and anticoagulation. Blood. 135(1), 2033-40. 10.1182/blood.2020006000.

Fox, S. E., et al. (2020). Pulmonary and cardiac pathology in African American patients with COVID-19: an autopsy series from New Orleans. Lancet Respir Med. 8(1), 681-86. 10.1016/S2213-2600(20)30243-5.

Gil, A. C. (2002). Como elaborar projetos de pesquisa. (4a ed.), Atlas, 2002.

Godoy, A. S. (1995). Introdução à pesquisa qualitativa e suas possibilidades. Revista de Administração de Empresas, 35(2), 57-63.

Goshua, G., et al. (2020). Endotheliopathy in COVID-19-associated coagulopathy: evidence from a single-centre, cross-sectional study. Lancet Haematol. 7(8), e575-e582. 10.1016/S2352-3026(20)30216-7.

IBA, T., et al. (2020). The unique characteristics of COVID-19 coagulopathy. Crit Care. 18(24), 360-9. 10.1186/s13054-020-03077-0.

Ibañez, C., et al. (2021). High D dimers and low global fibrinolysis coexist in COVID19 patients: what is going on in there? J Thromb Thrombolysis. 51(2), 308-312. 10.1007/s11239-020-02226-0.

Kamel, A. M., et al. (2021). Anticoagulation outcomes in hospitalized Covid-19 patients: A systematic review and meta-analysis of case-control and cohort studies. Rev Med Virol. 31(3), e2180. 10.1002/rmv.2180.

Leung, T. Y. M., et al. (2020). Short- and potential long-term adverse health outcomes of COVID-19: a rapid review. Emerg Microbes Infect. 9(1), 2190-2199. $10.1080 / 22221751.2020 .1825914$.

Libby, P. \& Lüscher, T. (2020). COVID-19 is, after all, an endothelial disease. Heart J. 41(1), 3038-3044.

Mcbane, R. D. 2ND, et al. (2020). Anticoagulation in COVID-19: A Systematic Review, Meta-analysis, and Rapid Guidance From Mayo Clinic. Mayo Clin Proc. 95(11), 2467-2486. 10.1016/j.mayocp.2020.08.030.

Pereira, A. S., Shitsuka, D. M., Parreira, F. J., Shitsuka, R. (2018). Metodologia da pesquisa científica. UFSM. https://repositorio.ufsm.br/bitstream/hand le/1/15824/Lic_Computacao_Metodologia-Pesquisa-Cientifica.pdf?sequence=1

Polimeni, A., et al. (2021). Differences in coagulopathy indices in patients with severe versus non-severe COVID-19: a meta-analysis of 35 studies and 6427 patients. Sci Rep. 17(11), 10464-68. 10.1038/s41598-021-89967-x.

Ranucci, M., et al. (2020). The procoagulant pattern of patients with COVID-19 acute respiratory distress syndrome. J Thromb Haemost. 18(1), 1747-51. $10.1111 /$ jth. 14854 .

Tang, N., et al. (2020). Abnormal coagulation parameters are associated with poor prognosis in patients with novel coronavirus pneumonia. $J$ Thromb Haemost. 18(1), 844-47. 10.1111/jth.14768.

Thachil, J., et al. (2020). ISTH interim guidance on recognition and management of coagulopathy in COVID-19. J Thromb Haemost. 18(1), 1023-26. $10.1111 /$ jth. 14810 .

Triviños, A. N. S. (1987). Introdução à pesquisa em ciências sociais: a pesquisa qualitativa em educação. Atlas, p. 100.

Uaprasert, N., et al. (2021). Systemic Coagulopathy in Hospitalized Patients With Coronavirus Disease 2019: A Systematic Review and Meta-Analysis. Clin Appl Thromb Hemost. 27(1), 076029620987629. 10.1177/1076029620987629.

Xiang, G, et al. (2021). The effect of coagulation factors in 2019 novel coronavirus patients: A systematic review and meta-analysis. Medicine (Baltimore). 19(100), e24537. 10.1097/MD.0000000000024537.

Zhang, X., et al. (2020). Coagulopathy in patients with COVID-19: a systematic review and meta-analysis. Aging (Albany NY). 24(12), 24535-24551. 10.18632/aging.104138.

Whittemore, R. \& Knafl, K. (2005). The integrative review: update methodology. J Adv Nurs. 52(5), 546-53. 